\title{
Rancang Bangun Company Profile E-Life Solutions PIt Berbasis Web Sebagai Corporate Branding
}

Nelsy Herman ${ }^{1,}$, Nur Zahrati Janah ${ }^{2}$

Teknik Informatika, Politeknik Negeri Batam

Teknik Multimedia dan Jaringan, Politeknik Negeri Batam

\begin{tabular}{l}
\hline Article Info \\
\hline Article history: \\
Received Oct $12^{\text {th }}, 2020$ \\
Revised Nov $20^{\text {th }}, 2020$ \\
Accepted Dec $16^{\text {th }}, 2020$ \\
\hline
\end{tabular}

\section{Keyword:}

Company profile

Corporate Branding

Website

Web Development Life Cycle

\begin{abstract}
E Life Solutions PLT (ELS) adalah sebuah perusahaan spin off dari Universiti Teknologi Malaysia (UTM) yang didirikan untuk mengkomersialkan fasilitas laboratorium dan keahlian di UTM. Perusahaan selalu memberikan informasi terbaru untuk meningkatkan reputasinya di pasar, mulai dari profil hingga produk dan jasa yang ditawarkan, namun kegiatan branding ELS saat ini masih tidak terstruktur. Kurangnya informasi jelas mengenai profil ELS, website yang tidak diperbaruhi isinya secara teratur, kaku dan kurang menarik sehingga menghambat dalam memberikan informasi. Untuk mengatasi masalah tersebut, maka diperlukan suatu website company profile yang dapat digunakan sebagai sarana promosi dan branding perusahaan. Oleh karena itu, penulis membangun website company profile sebagai corporate branding yang dapat memberikan informasi dan memperkuat branding perusahaan serta tampilan informasi pada website company profile E Life Solutions dapat diterima oleh pengguna. Website dibuat menggunakan CSS Framework, HyperText Markup Language (HTML), mySql dan PHP dengan menggunakan metode Website Development Life Cycle (WLDC). Website ini memiliki fitur home, about us, our business, our experieces, news dan contact us serta fitur tambahan seperti banner dan feedback form. Dengan tercapainya rata-rata persentase kepuasan antarmuka pengguna, website company profile E Life Solutions diterima dengan sangat baik oleh pengguna.
\end{abstract}

Copyright (C) 2020 Institute of Advanced Engineering and Science. All rights reserved.

\section{Corresponding Author:}

Teknik Informatika, Jurusan Teknik Informatika,

Politeknik Negeri Batam

Batam Centre, Jl. Ahmad Yani, Tlk. Tering, Kec. Batam Kota, Kepulauan Riau 29461

Email: nur.zahrati@polibatam.ac.id 


\section{PENDAHULUAN}

E Life Solutions PLT (ELS) adalah sebuah perusahaan spin off dari Universiti Teknologi Malaysia (UTM). ELS didirikan pada tahun 2016 untuk mengkomersialkan fasilitas laboratorium dan keahlian di UTM. Bisnis utama ELS adalah menyelenggarakan pelatihan dan kursus profesional untuk industri, melakukan studi, penelitian, pembangunan dan pengujian, pengadaan dan manajemen pelayanan produk, sistem dan kebijakan dalam bidang kesehatan, infrastruktur cerdas, industri teknologi tinggi, transportasi, telekomunikasi, minyak bumi dan gas, serta pertahanan dan keamanan.

Sebagai perusahaan saham terbuka, ELS memiliki banyak aktivitas dalam bidang biomedical, electrical, smart management dan informatics, yang mana cakupan pasarnya berada hampir diseluruh dunia seperti Kanada, Amerika, Brasil, Turki, Sudan, Mesir, Jerman, Irak, India, Brunei Darussalam, Rusia, Cina, Jepang, Korea Selatan, Thailand, Indonesia, Australia, dan Singapura. Untuk memperluas kawasan pasarnya, ELS melakukan berbagai kegiatan promosi dengan tujuan untuk meningkatkan reputasi perusahannya. Namun kegiatan branding ELS saat ini masih tidak terstruktur dan belum jelas, kurangnya informasi jelas mengenai profil ELS, website yang tidak diperbaruhi isinya secara teratur, kaku dan kurang menarik sehingga menghambat dalam memberikan informasi untuk perluasan kawasan pasarnya.

Dalam mempromosikan produk, pelatihan dan kursus yang ditawarkan, ELS hanya menggunakan statis website, media sosial, brosur. Akan tetapi, ketiga media promosi tidak diperbaruhi dan kurang menarik, informasi yang ditampilkan tidak lengkap. Untuk itu diperlukan sebuah media promosi yaitu website company profile yang dinamis dan menarik sebagai sarana corporate branding untuk membantu kegiatan promosi, sehingga pemberian informasi lebih cepat dan dapat menjangkau pasar yang lebih luas serta memperkuat daya tarik E-Life Solution sehingga para investor, organisasi ataupun masyarakat umum mengetahui lebih jelas mengenai informasi perusahaan dengan tujuan lebih tertarik untuk memberikan memberikan investasi di perusahaan, menggunakan layanan teknis dan klinis, membeli produk, bekerja sama dalam pemasaran dan juga meningkatkan pengembangan manusia.

Website company profile sebelumnya telah dibuat oleh beberapa sumber dengan berbagai pengembangan yang berbeda-beda sesuai dengan kebutuhannya diantaranya dilakukan oleh Rivai dan Ariyus. Website yang dirancang hanya fokus untuk penyampaian informasi dan promosi potensi budaya dari 14 pedukuhan yang ada di Desa Budaya Bumi Panggung yang menampilkan informasi lokasi potensi budaya, profil struktur organisasi, sejarah, gambar/foto potensi budaya beserta harga [1].

Ada juga penelitian oleh Anggoro mengenai pembuatan website company profile CV.Tunas Jaya berbasis website sebagai media promosi. Website ini terdiri dari visual gambar dan teks agar dapat memberikan informasi serta dapat dijadikan acuan dalam mengembangkan ide dan kreativitas dalam menciptakan media promosi suatu produk industri dalam media website [2].

Ada juga penelitian yang dilakukan oleh Susi yang telah merancang desain website sebagai media promosi Bandung Karate Club Kota Batam. Secara visual hanya terdapat teks dan gambar yang dapat memberikan informasi mengenai Bandung Karate Club [3].

Tabel 1 yang menjelaskan detail perbandingan sistem tiga penelitian yang telah disebutkan diatas dengan sistem yang telah penulis kembangkan.

Tabel 1. Perbandingan Sistem

\begin{tabular}{|l|l|l|l|l|}
\hline $\begin{array}{c}\text { Aspek } \\
\text { Pembeda }\end{array}$ & $\begin{array}{l}\text { Rivai dan } \\
\text { Ariyus [1] }\end{array}$ & $\begin{array}{c}\text { Anggo- } \\
\text { ro [2] }\end{array}$ & Susi [3] & $\begin{array}{l}\text { Peneltian } \\
\text { ini }\end{array}$ \\
\hline $\begin{array}{l}\text { Konek- } \\
\text { tivitas }\end{array}$ & $\begin{array}{l}\text { Local- } \\
\text { host }\end{array}$ & $\begin{array}{l}\text { Local- } \\
\text { host }\end{array}$ & $\begin{array}{l}\text { Local- } \\
\text { host }\end{array}$ & Internet \\
\hline $\begin{array}{l}\text { Jenis } \\
\text { website }\end{array}$ & Statis & Statis & Statis & Dinamis \\
\hline $\begin{array}{l}\text { Website } \\
\text { building }\end{array}$ & - & - & - & $\begin{array}{l}\text { CSS } \\
\text { Frame- } \\
\text { work }\end{array}$ \\
\hline $\begin{array}{l}\text { Respon- } \\
\text { sivitas }\end{array}$ & - & $\begin{array}{l}\text { Respon- } \\
\text { sif }\end{array}$ & - & \begin{tabular}{l} 
Responsif \\
\hline $\begin{array}{l}\text { Layout } \\
\text { website }\end{array}$
\end{tabular} \\
$\begin{array}{l}\text { Header, } \\
\text { navigasi, } \\
\text { content, } \\
\text { sidebar }\end{array}$ & $\begin{array}{l}\text { Header, } \\
\text { navi- } \\
\text { gasi, } \\
\text { content }\end{array}$ & $\begin{array}{l}\text { Hea-der, } \\
\text { navi- } \\
\text { gasi, } \\
\text { cont-ent }\end{array}$ & $\begin{array}{l}\text { Header, } \\
\text { navigasi, } \\
\text { content, } \\
\text { sidebar } \\
\text { dan footer }\end{array}$ \\
\hline
\end{tabular}

Dari ketiga penelitian yang telah ada tersebut, bahwa ketiganya mengembangkan website company profile yang hampir sama, hanya saja untuk jenis responsif website ada yang berbeda, yakni ada yang responsif dan ada juga yang tidak responsive. Ketiga website tersebut masih memiliki fungsionalitas yang terbatas yang mana hanya dapat diakses di local server saja dan jenis website bersifat statis.

Untuk itu penulis menawarkan solusi yang berbeda dari ketiga hasil penelitian yang telah disebutkan di atas. Solusi tersebut adalah membangun sebuah website company profile yang dinamis dan menarik sebagai sarana corporate branding untuk membantu kegiatan promosi, sehingga pemberian informasi lebih cepat dan dapat menjangkau pasar yang lebih luas serta memperkuat daya tarik E Life Solutions. 


\section{a) Company Profile}

Company profile adalah sebuah aset suatu lembaga atau perusahaan yang dapat digunakan untuk meningkatkan suatu image atau citra dari perusahaan untuk menjalin kerjasama dengan relasi perusahaan, lembaga dan instansi terkait lainnya [4]. Company profile merupakan penjelasan mengenai perusahaan yang mengangkat nilai perusahaan dan nilai produk serta keunggulan perusahaan dibandingkan pesaing [5].

\section{b) Corporate Branding}

Corporate branding merupakan penerapan dari penggunaan nama perusahaan sebagai suatu merek produk, nama perusahaan digunakan sebagai jaminan dari kualitas sebuah produk atau jasa yang ditawarkan oleh suatu organisasi atau perusahaan [6]. Corporate branding diperlukan karena berdampak pada perbedaan asosiasi perusahaan, memberikan energi bagi produk branding, meningkatkan kredibilitas, mendorong hubungan pembeli, menyediakan kekuatan rumah produksi yang mampu meningkatkan efisiensi atas produk brand baru. Corporate branding berfungsi sebagai alat kepemimpinan yang efektif. Salah satu karakteristik dari kepemimpinan yang kuat adalah kemampuan untuk mengkomunikasikan visi mereka ke dalam dan ke luar perusahaan [7].

\section{c) Heuristic Evaluation}

Heuristic evaluation sebuah usability inspection untuk memperbaiki sebuah rancangan secara efektif dengan menggunakan sekumpulan heuristik sederhana yang berhubungan. HE menjadi solusi untuk mengetahui masalah usability agar sistem dapat mencapai tujuan tertentu secara efektif, efisien, dan mencapai kepuasan pengguna. Proses dari HE memungkinkan sekumpulan evaluator yang secara independen untuk melakukan evaluasi dan menilai sistem dari setiap heuristik yang akan menunjukkan masalah usability [8].

Tabel 2. Tabel Heuristik Evaluation

\begin{tabular}{|c|l|l|}
\hline No & Heuristik & Definisi \\
\hline 1 & $\begin{array}{l}\text { H1-Visibility of } \\
\text { System Status }\end{array}$ & $\begin{array}{l}\text { Sistem harus selalu } \\
\text { menginformasikan kepada } \\
\text { pengguna terkait. }\end{array}$ \\
\hline 2 & $\begin{array}{l}\text { H2-Match } \\
\text { Between Sistem } \\
\text { and the Real } \\
\text { World }\end{array}$ & $\begin{array}{l}\text { Sistem menggunakan bahasa, } \\
\text { kata, kalimat, dan konsep yang } \\
\text { biasa digunakan dan mudah } \\
\text { dipahami oleh pengguna. }\end{array}$ \\
\hline 3 & $\begin{array}{l}\text { H3-User Control } \\
\text { and Freedom } \\
\text { User }\end{array}$ & $\begin{array}{l}\text { Dapat secara bebas memilih } \\
\text { dan melakukan pekerjaan } \\
\text { (sesuai kebutuhan) ketika } \\
\text { mengakses sistem. }\end{array}$ \\
\hline 4 & $\begin{array}{l}\text { H4- Consistency } \\
\text { and Standards } \\
\text { System }\end{array}$ & $\begin{array}{l}\text { Menjadi standar dan konsisten } \\
\text { dalam hal penulisan kalimat, } \\
\text { jenis huruf, dan lain sebagainya }\end{array}$ \\
\hline
\end{tabular}

\begin{tabular}{|c|c|c|}
\hline & & $\begin{array}{l}\text { sehingga pengguna tidak perlu } \\
\text { bingung dengan situasi dan } \\
\text { aksi yang berbeda pada sistem. }\end{array}$ \\
\hline 5 & $\begin{array}{l}\text { H5-Error } \\
\text { Prevention }\end{array}$ & $\begin{array}{l}\text { Merancang sebuah fitur untuk } \\
\text { mencegah dan meminimalisir } \\
\text { kesalahan dari pengguna. }\end{array}$ \\
\hline 6 & $\begin{array}{l}\text { H6- Recognition } \\
\text { Rather Than } \\
\text { Recall. }\end{array}$ & $\begin{array}{l}\text { Sistem membantu pengguna } \\
\text { untuk mengurangi mengingat } \\
\text { dari setiap proses yang telah } \\
\text { dilewati atau dilakukan karena } \\
\text { sudah jelas diinformasikan oleh } \\
\text { sistem. }\end{array}$ \\
\hline 7 & $\begin{array}{l}\text { H7- Flexibility } \\
\text { and Efficiency of } \\
\text { Use }\end{array}$ & $\begin{array}{l}\text { Sistem memberikan } \\
\text { kemudahan bagi pengguna } \\
\text { baru dan pengguna yang sudah } \\
\text { pengalaman untuk nyaman } \\
\text { dalam mengakses sistem. }\end{array}$ \\
\hline 8 & $\begin{array}{l}\mathrm{H} 8-\text { Aesthetic and } \\
\text { Minimalist Design }\end{array}$ & $\begin{array}{l}\text { Sistem menampilkan informasi } \\
\text { atau keterangan yang relevan } \\
\text { dengan maksud dari menu } \\
\text { yang dipilih. }\end{array}$ \\
\hline 9 & $\begin{array}{l}\text { H9-Helps } \\
\text { Pengguna } \\
\text { Recognize, } \\
\text { Diagnose, and } \\
\text { Recovers } \\
\text { Pengguna } \\
\end{array}$ & $\begin{array}{l}\text { Sistem menampilkan pesan } \\
\text { kesalahan yang terjadi dengan } \\
\text { jelas kepada pengguna. }\end{array}$ \\
\hline 10 & $\begin{array}{l}\mathrm{H} 10-\text { Help and } \\
\text { Documentation } \\
\text { syistem }\end{array}$ & $\begin{array}{l}\text { Harus memiliki menu bantuan } \\
\text { dan dokumentasi yang } \\
\text { membantu sebagai panduan } \\
\text { untuk pengguna saat } \\
\text { menggunakan sistem. }\end{array}$ \\
\hline
\end{tabular}

\section{d) Skala Likert}

Skala Likert ditemukan oleh Rensis Likert, seorang psikolog sosial asal Amerika Serikat. Skala likert digunakan untuk mengukur sikap dan pendapat responden terhadap sesuatu yang dituangkan dalam bentuk kuesioner. Kuesioner yang menggunakan skala likert diharuskan melengkapi pertanyaan atau pernyataan dengan tingkat persetujuan. Tingkat persetujuan dalam skala likert terdiri dari 5 tingkatan, yaitu: sangat setuju, setuju, ragu-ragu, tidak Setuju, dan sangat tidak setuju [9]. Adapun rumus perhitungan skala Likert sebagai berikut:

\section{Rumus Total Skor $=\mathbf{T} \times \mathbf{P n}$}

$\mathrm{T}=$ Total jumlah responden

Pn = Pilihan angka skor Likert

Setelah total skor didapatkan, selanjutnya yang harus dilakukan adalah menentukan index dalam persen dengan menggunakan rumus sebagai berikut:

\section{Rumus Index \% = Total skor/Y x 100}

Hasil perhitungan index akan dievaluasi dengan nilai akhir dan dirujuk dengan interval yang ada. Adapun rumus interval index dapat dihitung dan menghasilkan interval nilai index sebagai berikut: 


\section{Rumus Interval I = $100 /$ Jumlah Skor (Likert)}

Dengan jumlah skor Likert sebanyak 5 buah, maka interval index dapat dihitung dan menghasilkan interval sebagai berikut:
a. Angka index 0\% -19,99\% = Sangat Tidak Setuju
b. Angka index $20 \%-39,99 \%=$ Tidak Setuju
c. Angka index 40\% -59,99\% = Ragu-ragu
d. Angka index 60\% -79,99\% = Setuju
e. Angka index $80 \%-100 \%=$ Sangat Setuju

\section{METODE PENELITIAN}

Metode yang digunakan dalam pembuatan company website sebagai corporate branding adalah menggunakan metode Website Development Life Cycle (WDLC). WDLC merupakan sebuah proses pengembangan suatu sistem yang digunakan oleh analis sistem untuk mengembangkan sebuah website dan gambaran disampaikan kepada pengguna. Metode WLCD dilakukan dalam 5 tahap yaitu: website planning, website analysis, website design dan development, website testing, website implementation and maintenance [10].

\section{A. Planning}

\section{Konsep}

Konsep adalah tahapan untuk menentukan tujuan dan siapa pengguna program (identifikasi audience). Selain itu menentukan macam aplikasi (presentasi, interaktif, dain lain-lain) dan tujuan aplikasi.

Tabel 3. Konsep

\begin{tabular}{|c|c|}
\hline $\begin{array}{l}\text { Kategori } \\
\text { Konsep } \\
\end{array}$ & Deskripsi Konsep \\
\hline Judul & $\begin{array}{l}\text { Company profile E Life Solutions Plt } \\
\text { Berbasis Web Sebagai Corporate } \\
\text { Branding. }\end{array}$ \\
\hline Aplikasi & Company profile berbasis website. \\
\hline Tujuan & $\begin{array}{l}\text { Sebagai sarana corporate branding } \\
\text { untuk membantu kegiatan promosi, } \\
\text { sehingga pemberian informasi lebih } \\
\text { cepat dan dapat menjangkau pasar yang } \\
\text { lebih luas serta memperkuat daya tarik } \\
\text { E Life Solutions. }\end{array}$ \\
\hline Segmentasi & $\begin{array}{l}\text { Usia } 20 \text { tahun keatas kalangan } \\
\text { profesional, wilayah seluruh dunia. }\end{array}$ \\
\hline Sasaran & $\begin{array}{l}\text { Semua kalangan yang ingin mengetahui } \\
\text { lebih jelas tentang E Life Solutions. }\end{array}$ \\
\hline Visualisasi & $\begin{array}{l}\text { Website dinamis dengan responsif } \\
\text { layout yang dapat menampilkan } \\
\text { informasi perusahaan dalam bentuk } \\
\text { gambar, teks, warna. }\end{array}$ \\
\hline
\end{tabular}

Konsep pada pembuatan website ini adalah menggunakan moderen website yang mengutamakan kesederhanaan, keindahan, kepintaran, detail dan kebaikan yang disajikan dengan warna khas biru. Website ini mempunyai kerangka yang dibagi menjadi 3 bagian yaitu header yang berisi logo, nomor telefon dan alamat email perusahaan. Lalu navigasi terdiri dari 4 menu utama yaitu website berisi home, about us, our business, our experience, news dan contact us. Lalu footer yang berisi logo perusahaan, Copyright, gallery dan sosial media perusahaan. Website akan disajikan dalam bentuk artikel yang dilengkap dengan gambar serta video.

\section{B. Analysis}

a) Analisis Sistem

1. Admin

Bertugas untuk melakukan pengelolaan terhadap website seperti memasukan konten, memperbaruhi konten dan menghapus konten. Konten berupa artikel news yang akan ditampilkan.

2. Pengguna

Pengguna memiliki hak akses untuk membaca, mendapatkan informasi tentang perusahaan yang tersedia dari website. Pengguna dapat mengisi feedback form. Gambar 1 merupakan gambar yang menjelaskan deskripsi umum sistem.

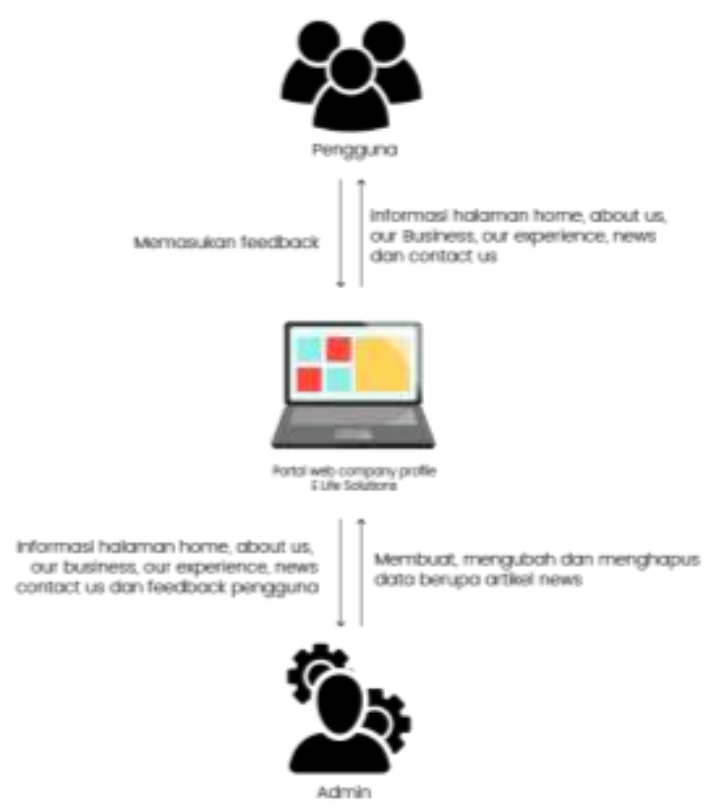

Gambar 1 Deskripsi umum sistem

\section{Diagram Usecase}

Diagram use case menerangkan apa saja yang dilakukan oleh pengguna terhadap sistem. Sebuah sist

$\mathrm{Dal}$

unt

keg

pro.

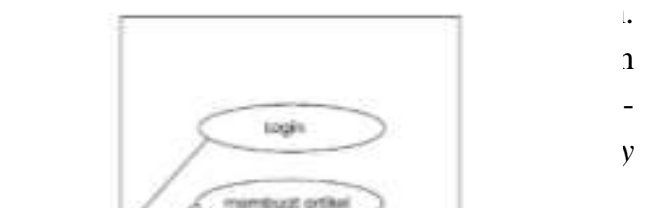


Gambar 2 Use case diagram

\section{Design and Development}

a) Perancangan Antarmuka Pengunjun

1. Home

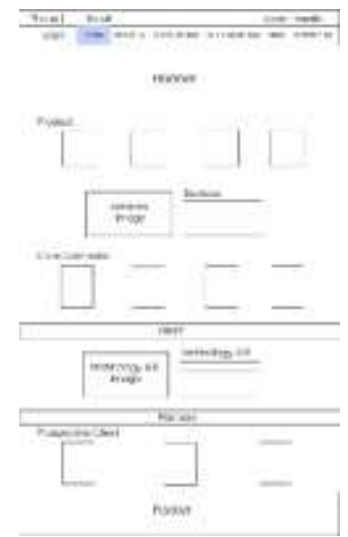

Gambar 3 Halaman Home

2. About Us

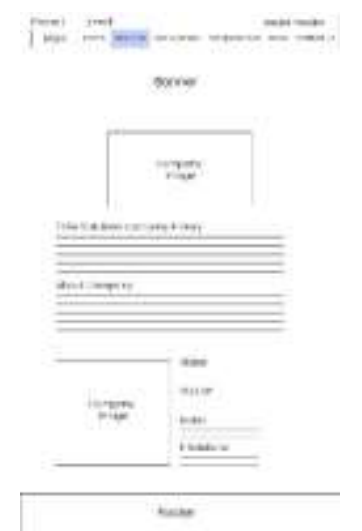

Gambar 4 Halaman About Us

3. Our Business

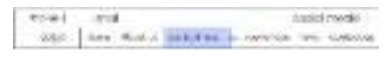

some
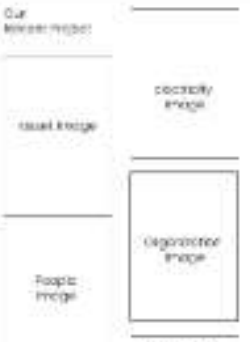

$\overline{\text { invinuetes }}$

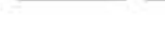

Gambar 5 Halaman Our Business.

4. Our Experience

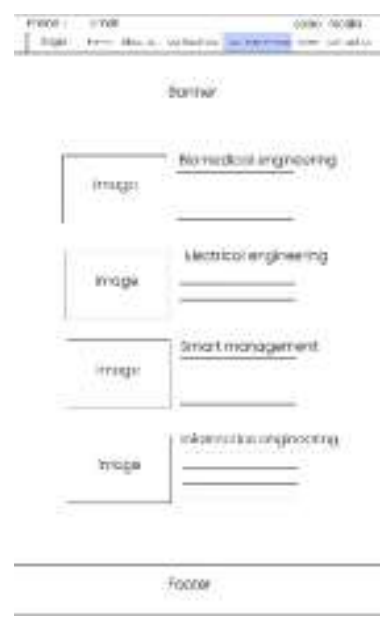

Gambar 6 Halaman Our Experience

5. News

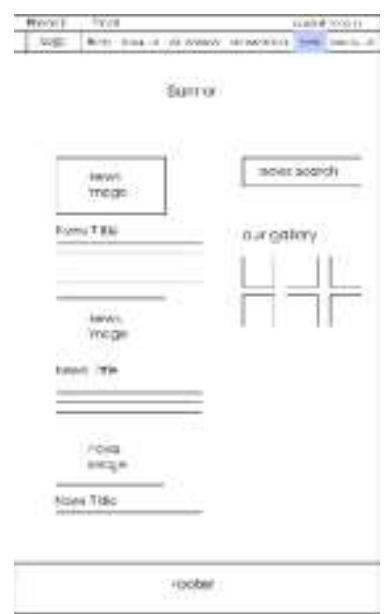

Gambar 7 Halaman News

6. Contact Us 


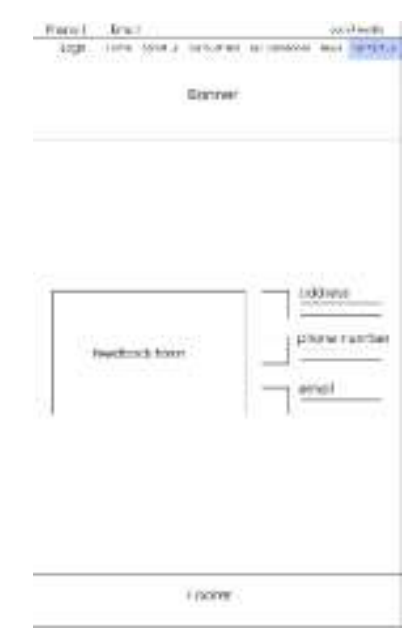

Gambar 8 Halaman contact us

\section{Testing}

Pengujian website company profile E Life Solutions dengan menerapkan model analisis Heuristic evaluation [6].

a) Instrumen Analisis Data

Bentuk instrumen analisis data yang dipakai dalam penelitian ini dalam bentuk Kuesioner menggunakan skala likert. Kuesioner dibuat berdasarkan indikator pada heuristic evalution untuk mengevaluasi usability website.

b) Teknik Pengolahan dan Analisis Data

Penelitian ini menggunakan analisis kuantitatif menggunakan metode heuristic evaluation. Analisis kuantitatif yang bertujuan untuk memperoleh presentase dari hasil kuesioner pengguna yang dianalisis secara deskriptif. Dari hasil perhitungan persentase, digunakan skala sebagai pedoman pendeskripsian usability website. Pengujian ini akan dilaksanakan dalam 2 tahap yaitu pengujian internal dan pengujian eksternal

\section{HASIL DAN ANALISIS}

a) Hasil Implementasi

Website company profile E Life Solutions memiliki beberapa halaman yang memiliki desain layout dan fungsi yang berbeda. Fungsi tersebut dibedakan menjadi tombol yang digunakan untuk memanggil suatu fungsi serta teks dan gambar yang digunakan untuk memberikan penjelasan pada tampilan tersebut.
1) Halaman Home

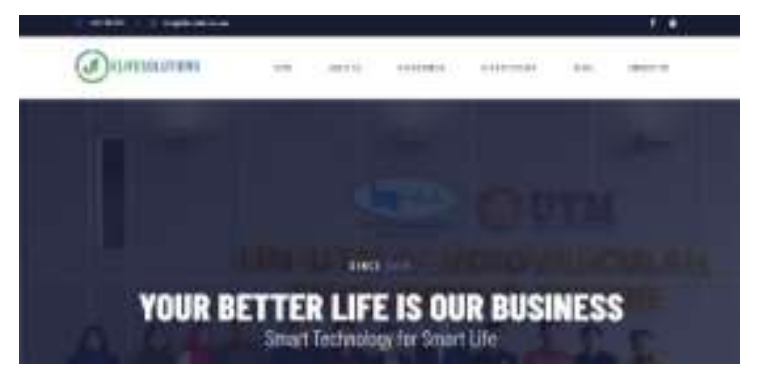

Gambar 9 Halaman home

Tampilan halaman terdapat informasi mengenai produk, kompetensi inti dan teknologi 4.0 yang mana gambar tersebut akan dihubungkan menuju halaman berdasarkan kategorinya. Pada halaman home juga menampilkan klien, partner serta prospek klien dalam bentuk gambar.

a) Halaman About Us
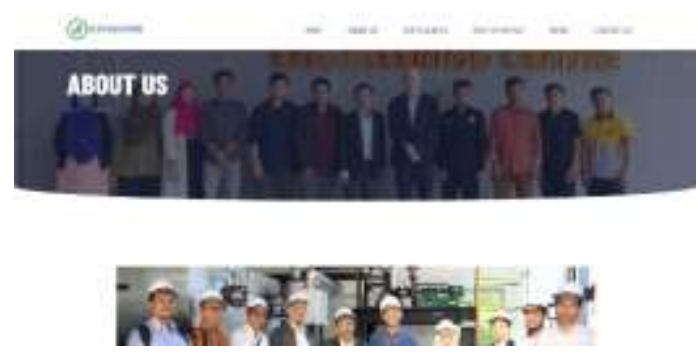

\section{Gambar 10 Halaman about us}

Halaman ini menjelaskan tentang sejarah singkat perusahaan yang akan disajikan dalam bentuk gambar dan penjelasannya, lalu dilanjutkan dengan visi, misi dan motto perusahaan. Selanjutnya akan menjelaskan tentang struktur organisasi perusahaan.

b) Halaman Our business

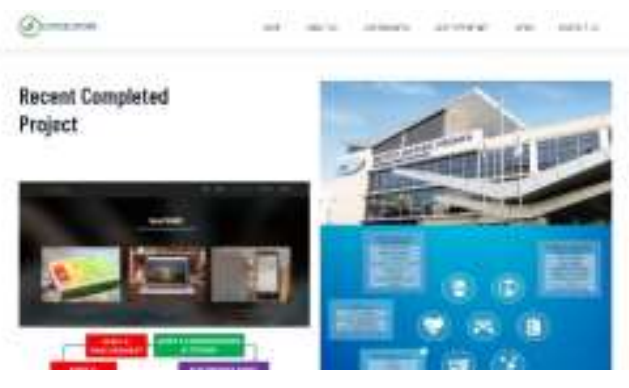

Gambar 11 Halaman our business

Halaman ini menjelaskan tentang produk dan jasa yang ditawarkan. Produk yang diunggulkan oleh perusahaan. Produk akan dijelaskan dengan gambar dan artikel. 
c) Halaman Our experience

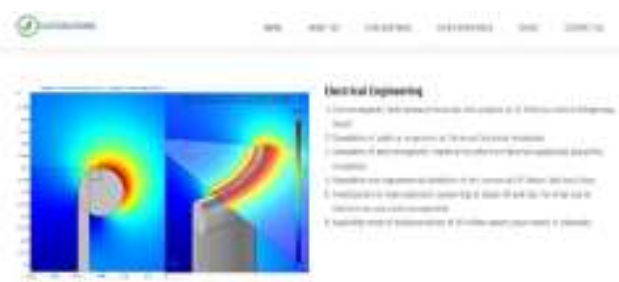

Gambar 12 Halaman our experience

Halaman ini menjelaskan tentang kegiatan yang telah dilakukan seperti produk atau jasa yang telah dibuat lalu penghargaan yang diterima oleh perusahaan.

d) Halaman News

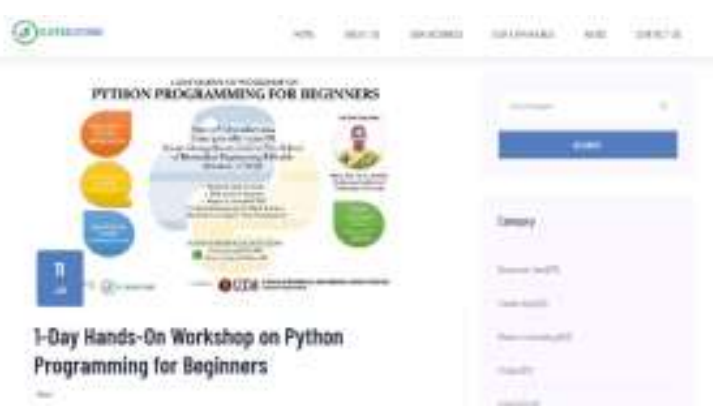

Gambar 13 Halaman news

Halaman ini menjelaskan tentang berita, ataupun informasi-informasi yang berhubungan dengan kegiatan perusahaan. Berita akan diperbaruhi setiap harinya.

e)

Halaman Contact us

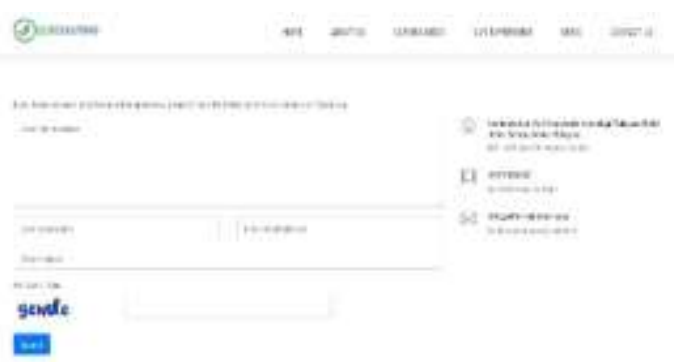

Gambar 14 Halaman contact us

Halaman ini menjelaskan tentang kontak perusahaan yang dapat dihubungi seperti terdapat peta perusahaan, feedback form, alamat perusahaan, nomor telepon serta email perusahaan. Data disajikan dalam bentuk icon dan artikel pendukung. f) Halaman Login Admin

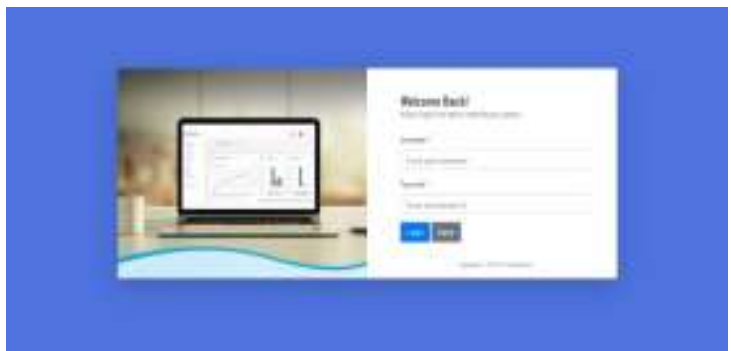

Gambar 15 Halaman login admin

Login admin merupakan tampilan pertama saat admin mengakses halaman admin untuk mengolah data. Halaman login terdiri dari form penggunaname, password dan tombol login.

\section{g) Halaman Dashboard Admin}

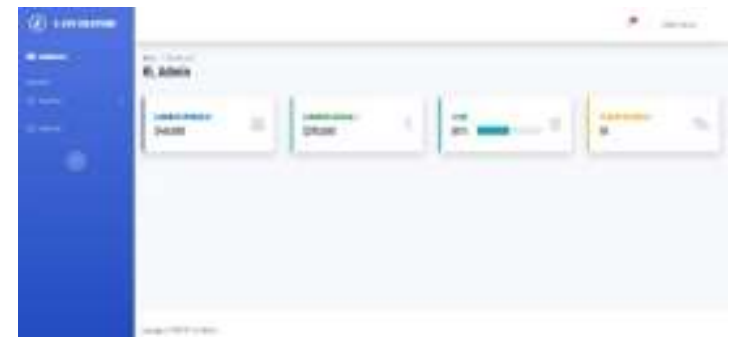

Gambar 16 Halaman dashboard admin

Ketika admin berhasil masuk, maka admin dapat masuk ke halaman dashboard untuk mengolah data seperti menambah data, memperbarui data dan menghapus data.

\subsection{Analisis}

Analisis ini bertujuan untuk mengukur tingkat persetujuan pengguna terhadap tampilan informasi pada company profile E Life Solutions berbasis website. Hasil yang didapat berupa persentase dari hasil kuesioner pengguna yang dianalisis secara deskriptif apakah pengguna setuju terhadap tampilan informasi website. Pengujian ini akan dilaksanakan dalam 2 tahap, yaitu:

\section{Evaluasi tahap 1 (pengujian internal)}

Dilakukan pengujian secara blackbox untuk menguji keberhasilan implementasi kebutuhan fungsional maupun non fungsional. Evaluasi tahap 1 merupakan evaluasi awal terhadap website company profile E Life Solutions. Evaluasi ini dilakukan secara langsung oleh dua evaluator perusahaan dalam mengeksplorasi website $\mathrm{E}$ Life Solutions, untuk memastikan kebutuhan fungsional dan non fungsional website terpenuhi. 
Tabel 4. Pengujian Internal

\begin{tabular}{|c|c|c|c|}
\hline No & $\begin{array}{l}\text { Nama } \\
\text { Proses }\end{array}$ & Data Uji & Validasi \\
\hline 1 & Login & $\begin{array}{l}\text { Login } \\
\text { menggunakan } \\
\text { penggunaname dan } \\
\text { password yang } \\
\text { terdaftar. }\end{array}$ & berhasil \\
\hline 2 & $\begin{array}{l}\text { CRUD } \\
\text { Data }\end{array}$ & $\begin{array}{lr}\text { Dapat } & \text { memasukan } \\
\text { data, memperbarui } \\
\text { dan menghapus } \\
\text { data artikel news } \\
\text { dan menampilkan } \\
\text { datar }\end{array}$ & berhasil \\
\hline 3 & Feedback & $\begin{array}{l}\text { Dapat memasukan } \\
\text { data feedback dan } \\
\text { sistem dapat } \\
\text { menampilkan data. }\end{array}$ & berhasil \\
\hline \multirow{4}{*}{4} & \multirow{4}{*}{ Usability } & $\begin{array}{l}\text { Informasi } \\
\text { perusahaan jelas } \\
\text { dan akurat (teks, } \\
\text { gambar). }\end{array}$ & berhasil \\
\hline & & Website responsif. & berhasil \\
\hline & & $\begin{array}{l}\text { Tampilan } \\
\text { visualisasi website } \\
\text { sesuai dengan } \\
\text { permintaan } \\
\text { perusahaan (warna, } \\
\text { typografi, desain } \\
\text { dan gambar). }\end{array}$ & berhasil \\
\hline & & $\begin{array}{l}\text { Tampilan website } \\
\text { sudah menunjukan } \\
\text { branding } \\
\text { perusahaan. }\end{array}$ & berhasil \\
\hline
\end{tabular}

2. Evaluasi tahap 2 (Pengujian eksternal)

Evaluasi tahap 2 merupakan proses evaluasi pengguna interface website yang akan dilakukan oleh pengguna menggunakan Heuristic evaluation. Pengujian akan diberikan kepada 30 responden yaitu masyarakat umum dengan menggunakan skala likert. Hasil data kuesioner dari 30 responden yang diambil dari 11 Karyawan perusahaan E Life Solutions, 10 dari kalangan professional dan 9 mahasiswa secara rinci:

Tabel 5. Kuesioner Pengguna

\begin{tabular}{|l|l|l|l|l|l|l|}
\hline HE & Pertanyaan SS & S & $\begin{array}{l}\text { R } \\
\text { G }\end{array}$ & TS & STS \\
\hline H2 & $\begin{array}{l}\text { Website } \\
\text { menggunakan kata } \\
\text { dan frasa yang } \\
\text { akrab pada } \\
\text { pengguna }\end{array}$ & 18 & 12 & 0 & 0 & 0 \\
\hline H4 & $\begin{array}{l}\text { Desain antarmuka } \\
\text { konsisten setiap } \\
\text { halaman. }\end{array}$ & 16 & 14 & 0 & 0 & 0 \\
\hline H8.1 & $\begin{array}{l}\text { Tampilan website } \\
\text { responsif. }\end{array}$ & 25 & 5 & 0 & 0 & 0 \\
\hline
\end{tabular}

\begin{tabular}{|c|c|c|c|c|c|c|}
\hline H8.2 & $\begin{array}{l}\text { Tampilan desain } \\
\text { dan visualisasi } \\
\text { menarik. }\end{array}$ & 24 & 6 & 0 & 0 & 0 \\
\hline H8.3 & $\begin{array}{l}\text { Tampilan estetika } \\
\text { warna menarik }\end{array}$ & 22 & 8 & 0 & 0 & 0 \\
\hline H8.4 & $\begin{array}{l}\text { Tampilan font dan } \\
\text { ukuran font } \\
\text { proporsional. }\end{array}$ & 17 & 13 & 0 & 0 & 0 \\
\hline H8.5 & $\begin{array}{l}\text { Tampilan layout } \\
\text { website } \\
\text { proporsional. }\end{array}$ & 18 & 12 & 0 & 0 & 0 \\
\hline H8.6 & $\begin{array}{l}\text { Tampilan informasi } \\
\text { mudah dibaca, } \\
\text { dipahami dan } \\
\text { dimengerti }\end{array}$ & 19 & 11 & 0 & 0 & 0 \\
\hline H8.7 & $\begin{array}{l}\text { Tampilan informasi } \\
\text { gambar dan video } \\
\text { proporsional }\end{array}$ & 14 & 16 & 0 & 0 & 0 \\
\hline
\end{tabular}

Skor pada masing-masing pernyataan di atas akan dihitung menggunakan rumus total skor, yaitu skor jumlah responden yang memilih dikalikan dengan pilihan angka skor likert. Berikut perhitungan kuesioner dari hasil uji secara rinci:

a) Pernyataan $\mathrm{H} 2$ "Website menggunakan kata dan frasa yang akrab pada pengguna". Hasil hitung Skor likert pada pernyataan $\mathrm{H} 2$ disajikan pada tabel berikut:

\begin{tabular}{|c|c|c|c|c|c|}
\hline \multicolumn{6}{|c|}{$\begin{array}{c}\text { Tabel 6. Hasil perhitungan } \\
\text { Pernyatan dan Hasil pengujian }\end{array}$} \\
\hline \multirow{2}{*}{$\begin{array}{l}\text { Pernyataan } \\
\text { Penilaian }\end{array}$} & \multicolumn{5}{|c|}{$\begin{array}{l}\text { Website menggunakan kata dan frasa } \\
\text { yang akrab pada pengguna }\end{array}$} \\
\hline & SS & $\mathrm{S}$ & RG & TS & STS \\
\hline Jumlah responden & 18 & 12 & 0 & 0 & 0 \\
\hline Total Responden & \multicolumn{5}{|l|}{30} \\
\hline Jumlah & \multicolumn{5}{|c|}{$(18 * 5)+(12 * 4))+(0 * 3)+(0 * 2)+(0 * 1)$} \\
\hline Skor likert & \multicolumn{5}{|c|}{$(138 / 150) * 100=92 \%$} \\
\hline
\end{tabular}

Berdasarkan hasil perhitungan skor likert pada tabel perhitungan $\mathrm{H} 2$, nilai persentase kepuasan pengguna terhadap tampilan aplikasi mencapai $92 \%$ yang berarti pengguna sangat setuju dengan pernyataan "Website menggunakan kata dan frasa yang akrab pada pengguna".

b) Pernyataan $\mathrm{H} 4$ "Desain antarmuka konsisten setiap halaman". Hasil hitung skor likert pada pernyataan H4 disajikan pada tabel berikut:

Tabel 7. Hasil perhitungan $\mathrm{H} 4$

\begin{tabular}{|l|l|l|l|l|l|}
\hline \multicolumn{5}{|c|}{ Pernyatan dan Hasil pengujian } \\
\hline Pernyataan & $\begin{array}{l}\text { Desain antarmuka konsisten setiap } \\
\text { halaman }\end{array}$ \\
\hline Penilaian & SS & S & RG & TS & STS \\
\hline
\end{tabular}




\begin{tabular}{|l|l|l|l|l|l|}
\hline Jumlah responden & 16 & 14 & 0 & 0 & 0 \\
\hline Total Responden & 30 & & & & \\
\hline Jumlah & $\left.\left(16^{*} 5\right)+(14 * 4)\right)+(0 * 3)+(0 * 2)+(0 * 1)$ \\
\hline Skor $l$ likert & $(136 / 150 * 100=90 \%$ \\
\hline
\end{tabular}

Berdasarkan hasil perhitungan skor likert pada tabel perhitungan $\mathrm{H} 4$, nilai persentase kepuasan pengguna terhadap tampilan aplikasi mencapai $90 \%$ yang berarti pengguna sangat setuju dengan pernyataan "Desain antarmuka konsisten setiap halaman".

c) Pernyataan H8.1 "Tampilan website responsif". Hasil hitung Skor likert pada pernyataan H8.1 disajikan pada tabel berikut:

Tabel 8. Hasil perhitungan H8.1

\begin{tabular}{|l|l|l|l|l|l|}
\hline \multicolumn{5}{|c|}{ Pernyatan dan Hasil pengujian } \\
\hline Pernyataan & \multicolumn{4}{|l|}{ Tampilan website responsif } \\
\hline Penilaian & SS & S & RG & TS & STS \\
\hline Jumlah responden & 25 & 5 & 0 & 0 & 0 \\
\hline Total Responden & 30 & \multicolumn{5}{l}{} \\
\hline Jumlah & $(25 * 5)+(5 * 4))+(0 * 3)+(0 * 2)+\left(0^{*} 1\right)$ \\
\hline Skor likert & $(145 / 150) * 100=96,6 \%$ \\
\hline
\end{tabular}

Berdasarkan hasil perhitungan skor likert pada tabel perhitungan H8.1, nilai persentase kepuasan pengguna terhadap tampilan aplikasi mencapai 96.6\% yang berarti pengguna sangat setuju dengan pernyataan "Tampilan website responsif".

d) Pernyataan H8.2 "Tampilan desain dan visualisasi menarik". Hasil hitung Skor likert pada pernyataan H8.2 disajikan pada tabel berikut:

Tabel 9. Hasil perhitungan H8.2

\begin{tabular}{|l|l|l|l|l|l|}
\hline \multicolumn{5}{|l|}{ Pernyatan dan Hasil pengujian } \\
\hline Pernyataan & $\begin{array}{l}\text { Tampilan desain } \\
\text { menarik }\end{array}$ \\
\hline Penilaian & SS & S & RG & TS & STS \\
\hline Jumlah responden & 24 & 6 & 0 & 0 & 0 \\
\hline Total Responden & 30 & \multicolumn{5}{l|}{} \\
\hline Jumlah & \multicolumn{5}{|l|}{$(24 * 5)+(6 * 4))+(0 * 3)+(0 * 2)+(0 * 1)$} \\
\hline Skor likert & $(144 / 150) * 100=96 \%$ \\
\hline
\end{tabular}

Berdasarkan hasil perhitungan skor likert pada tabel perhitungan $\mathrm{H} 8.2$, nilai persentase kepuasan pengguna terhadap tampilan aplikasi mencapai $96.6 \%$ yang berarti pengguna sangat setuju dengan pernyataan "Tampilan desain dan visualisasi menarik".

e) Pernyataan H8.3 “Tampilan estetika warna menarik". Hasil hitung Skor likert pada pernyataan $\mathrm{H} 2$ disajikan pada tabel berikut:

Tabel 10. Hasil perhitungan H8.3

\begin{tabular}{|l|l|l|l|l|l|}
\hline \multicolumn{6}{|c|}{ Pernyatan dan Hasil pengujian } \\
\hline Pernyataan & \multicolumn{4}{|l|}{ Tampilan estetika warna menarik } \\
\hline Penilaian & SS & S & RG & TS & STS \\
\hline Jumlah responden & 22 & 8 & 0 & 0 & 0 \\
\hline Total Responden & \multicolumn{3}{|l|}{30} \\
\hline Jumlah & $\left.(22 * 5)+\left(8^{*} 4\right)\right)+(0 * 3)+(0 * 2)+(0 * 1)$ \\
\hline Skor likert & $(142 / 150) * 100=94.6 \%$ \\
\hline
\end{tabular}

Berdasarkan hasil perhitungan skor likert pada tabel perhitungan $\mathrm{H} 8.3$, nilai persentase kepuasan pengguna terhadap tampilan aplikasi mencapai 94.6\% yang berarti pengguna sangat setuju dengan pernyataan "Tampilan estetika warna menarik".

f) Pernyataan H8.4 "Tampilan font dan ukuran font proporsional". Hasil hitung Skor likert pada pernyataan $\mathrm{H} 2$ disajikan pada tabel berikut:

Tabel 11. Hasil perhitungan H8.4

\begin{tabular}{|l|l|l|l|l|l|}
\hline \multicolumn{5}{|c|}{ Pernyatan dan Hasil pengujian } \\
\hline Pernyataan & $\begin{array}{l}\text { Tampilan font dan ukuran font } \\
\text { proporsional }\end{array}$ \\
\hline Penilaian & SS & S & RG & TS & STS \\
\hline Jumlah responden & 17 & 13 & 0 & 0 & 0 \\
\hline Total Responden & 30 & & & & \\
\hline Jumlah & $(17 * 5)+(13 * 4))+(0 * 3)+(0 * 2)+(0 * 1)$ \\
\hline Skor likert & $(137 / 150) * 100=91 \%$ \\
\end{tabular}

Berdasarkan hasil perhitungan skor likert pada tabel perhitungan $\mathrm{H} 8.4$, nilai persentase kepuasan pengguna terhadap tampilan aplikasi mencapai $91 \%$ yang berarti pengguna sangat setuju dengan pernyataan "Tampilan font dan ukuran font proporsional".

g) Pernyataan H8.5 "Tampilan layout website proporsional". Hasil hitung Skor likert pada pernyataan $\mathrm{H} 2$ disajikan pada tabel berikut: 
Tabel 12. Hasil perhitugan H8.5

\begin{tabular}{|l|l|l|l|l|l|}
\hline \multicolumn{5}{|l|}{ Pernyatan dan Hasil pengujian } \\
\hline Pernyataan & \multicolumn{5}{|l|}{ Tampilan layout website proporsional } \\
\hline Penilaian & SS & S & RG & TS & STS \\
\hline Jumlah responden & 18 & 12 & 0 & 0 & 0 \\
\hline Total Responden & 30 & & & & \\
\hline Jumlah & $(17 * 5)+(13 * 4))+(0 * 3)+(0 * 2)+(0 * 1)$ \\
\hline Skor likert & $(138 / 150) * 100=92 \%$ \\
\hline
\end{tabular}

Berdasarkan hasil perhitungan skor likert pada tabel perhitungan H8.5, nilai persentase kepuasan pengguna terhadap tampilan aplikasi mencapai $92 \%$ yang berarti pengguna sangat setuju dengan pernyataan "Tampilan layout website proporsional".

h) Pernyataan H8.6 "Tampilan informasi mudah dibaca, dipahami dan dimengerti”. Hasil hitung Skor likert pada pernyataan $\mathrm{H} 2$ disajikan pada tabel berikut:

Tabel 13. Hasil perhitugan H8.6

\begin{tabular}{|l|l|l|l|l|l|}
\hline \multicolumn{5}{|l|}{ Pernyatan dan Hasil pengujian } \\
\hline Pernyataan & \multicolumn{3}{l|}{$\begin{array}{l}\text { Tampilan informasi mudah dibaca, } \\
\text { dipahami dan dimengerti }\end{array}$} \\
\hline Penilaian & SS & S & RG & TS & STS \\
\hline Jumlah responden & 19 & 11 & 0 & 0 & 0 \\
\hline Total Responden & 30 & \multicolumn{5}{l|}{} \\
\hline Jumlah & \multicolumn{5}{|l|}{$(19 * 5)+(11 * 4))+(0 * 3)+(0 * 2)+(0 * 1)$} \\
\hline Skor likert & $(139 / 150)^{*} 100=92,6 \%$ \\
\hline
\end{tabular}

Berdasarkan hasil perhitungan skor likert pada tabel perhitungan H8.6, nilai persentase kepuasan pengguna terhadap tampilan aplikasi mencapai $91 \%$ yang berarti pengguna sangat setuju dengan pernyataan "Tampilan informasi mudah dibaca, dipahami dan dimengerti”.

i) Pernyataan H8.7 "Tampilan informasi gambar dan video proporsional". Hasil hitung Skor likert pada pernyataan $\mathrm{H} 2$ disajikan pada tabel berikut:

\begin{tabular}{|l|l|l|l|l|l|}
\hline \multicolumn{5}{|l|}{ Pernyatan dan Hasil pengujian } \\
\hline Pernyataan & $\begin{array}{l}\text { Tampilan informasi gambar dan video } \\
\text { proporsional }\end{array}$ \\
\hline Penilaian & SS & S & RG & TS & STS \\
\hline Jumlah responden & 14 & 16 & 0 & 0 & 0 \\
\hline Total Responden & 30 & \multicolumn{5}{l|}{} \\
\hline Jumlah & \multicolumn{5}{|l|}{$\left.(14 * 5)+\left(16^{*} 4\right)\right)+(0 * 3)+(0 * 2)+(0 * 1)$} \\
\hline Skor likert & \multicolumn{5}{l}{} \\
\hline
\end{tabular}

Berdasarkan hasil perhitungan skor likert pada tabel perhitungan $\mathrm{H} 8.7$, nilai persentase kepuasan pengguna terhadap tampilan aplikasi mencapai $89 \%$ yang berarti pengguna sangat setuju dengan pernyataan "Tampilan informasi gambar dan video proporsional".

Jika diamati secara keseluruhan, maka hasil dari tampilan informasi pada company profile $\mathrm{E}$ Life Solutions berbasis website dapat disajikan sebagai berikut:

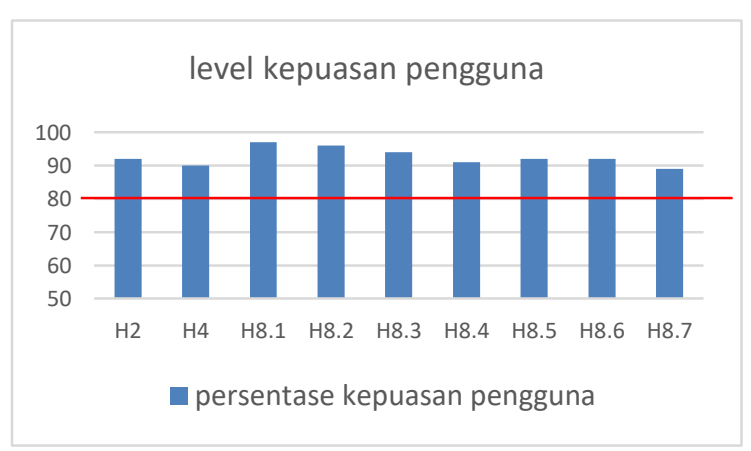

Gambar 17 Hasil persentase kuesioner pengguna

Hasil pada kuesioner di atas jika mengacu pada interval angka index tingkat persetujuan pengguna, maka minimal angka yang harus dicapai untuk bisa masuk dalam kategori disetujui ialah $60 \%$. Secara keseluruhan, rata - rata dari persentase kepuasan pelanggan dari setiap kategori pernyataan adalah 92\%. Dari hasil tersebut dapat disimpulkan bahwa penggun sudah sangat setuju dengan desain antarmuka dan kegunaan yang dipersembahkan oleh website company profile E Life Solutions.

Tabel 14. Hasil perhitugan H8.7 


\section{KESIMPULAN}

a) Kesimpulan

Berdasarkan dari seluruh proses pengerjaan penelitian ini, penulis dapat menyimpulkan beberapa hal, antara lain:

1. Website company profile telah berhasil dibangun sebagai corporate branding yang menampilkan informasi tentang perusahaan. Website dibuat menggunakan, CSS Framework, HyperText Markup Language (HTML), mySql dan PHP dengan menggunakan metode Website Development Life Cycle (WLDC).

2. Website bersifat dinamis yang mana admin dapat mengubah konten pada website, lalu website bersifat responsif yang mana layout fleksibel menyesuaikan perangkat, memiliki fitur home, about us, our business, our experieces, news dan contact us serta fitur tambahan seperti banner dan feedback form.

3. Seluruh persentase interval index pada model analisis heuristic evaluation mencapai kategori sangat setuju (H2: 92\%, H4: 90\%, H8.1: 97\%, H8.2: 96\%, H8.3: 94\%, H8.4: 91\%, H8.5: 92\%, \%, H8.6: 92\%, \%, H8.7: 89\%). Dengan capaian rata-rata persentase kepuasan mencapai $92 \%$, antarmuka pengguna website company profile $\mathrm{E}$ Life Solutions diterima dengan sangat baik oleh pengguna.

b) Saran

Dari pembuatan website company profile sebagai corporate branding, $\mathrm{Tt}$ erdapat saran yang dapat digunakan untuk pengembangan selanjutnya sebagai berikut:

1) Website dapat menyajikan data yang lebih banyak dan lebih lengkap.

2) Website ini akan lebih sempurna bila dikembangkan dengan adanya fitur chat secara online pada website, sehingga pengguna lebih cepat mengakses informasi tentang perusahaan.

3) Antar pengguna dapat berbalas komentar pada halaman news sehingga dapat berbagi informasi.

\section{DAFTAR PUSTAKA}

[1] Fajar Irvan Rifai, Doni Ariyus. 2019, Perancangan website desa budaya bumi panggung sebagai media informasi dan promosi. Universitas Amikom Yogyakarta.

[2] Anggoro, Bimo Ruwandra Tri, 2016. Pembuatan Website Company profile CV.Tunas Jaya ASP.NET Sebagai Media Promosi. Universitas STIKOM, UYYUSurabaya.

[3] Susi, Hatri. 2017, Perancangan Desain Website Sebagai Media Promosi Bandung Karate Club Kota Batam. Politeknik Negeri Batam.

[4] Maimunah, Lusyani Sunarya and Nini Larasati, 2012. Media Company profile Sebagai Sarana
Penunjang Informasi dan Promosi, Tanggerang: Nini Larasati.

[5] Budiman. 2008. Company profile. Jakarta: Universitas Gunadarma.

[6] David A. Aaker. 2004. Leveraging the Corporate Brand. California Management Review: Vol. 46, No. 3.

[7] M.T. Balmer \& Edmund R. Gray. 2003 Corporate brands: what are they? What of them?. John European Journal of Marketing Vol. 37 No. 7/8, pp. 972-997.

[8] Dix, Alan, Finlay, Janet, M., 2010. HumanComputer Interaction Third Edition. UK: Pearson.

[9] Nur, Fikri Muhammad, 2019. 3D Visualization Design of Realtime Position Tracker Based On Ultra-Wideband Device.

[10] Kamatchi, R. et al. 2013. Software Engineering:Website Development LifeCycle International Journal of Engineering Research \& Technology.

[11] Nugroho, Adi. 2019. Rekayasa Perangkat Lunak Menggunakan UML \& Java. Yogyakarta: CV. Andi Offse. 